\title{
Effects of Entrepreneurship on The Performance of Organic Rice Farmers in Tasikmalaya Regency
}

\author{
Candra Nuraini ${ }^{1, *}$, Iskandar Ma'moen ${ }^{1}$ \\ ${ }^{1,2}$ University of Siliwangi, Agribusiness, Tasikmalaya
}

\begin{abstract}
This study aims to analyzethe influence of the rice organic farmers' entrepreneurship on the farming performance and identify the influence of farming technique or activities on the farming performance. This study used a survey method. The study was conducted in Manonjaya and Salawu sub-districts, Tasikmalaya regency, August until November 2019 which was chosen using purposive sampling technique applied to 50 samples. The respondents who were organic rice farmers were recruited using multistage purposive sampling technique. Data analysis was performed using structural equation modeling (SEM) with WarpPLS 2.0. The result show that the entrepreneurship significantly and positively affects farming techniques. Entrepreneurship has significant and positive influence on the organic rice farming performance. In addition, farming technique is significantly and positively influential on the organic rice farming performance.
\end{abstract}

\section{Introduction}

In general, there are two types of farmers: farmers who have restricted diversification and farmers who have entrepreneurship with the following characteristics: overwhelmed with opportunities in agriculture, orientation in entrepreneurship, decisions made practically, risk-taker in nature and competition with other ventures [1]. Based on [2] entrepreneurship allows farmers to take advantage of technology to grow the farms. Additionally, agriculture has a more important role now; not only does agriculture intensify the food production, but also supports the growth of rural areas [3]. Successful entrepreneurs possess orientation in entrepreneur- ship are marketing and realize that it is important to utilize technology in agriculture.

Organic rice farming is an implementation of sustainable farming technology. It requires a conversion or transition period from conventional to organic system. The initial stage of the organic farming implementation has become a challenge for farmers to continue and sustain the farming. [4] Farming is often characterized by high variability of production results or great risks. Farming products are dependent on climates, pests, weather, diseases, as well as the volatility of input and output prices. All of these contribute to the market risk. Agricultural commodity prices often fluctuate and lack stability and certainty.

*Corresponding author: candranuraini@unsil.ac.id 
Such condition leads to farmers' intention to return from organic farming system to conventional farming system. From the business standpoint, organic farming system has a strong potential to offer business opportunities because organic rice is a premium agricultural product that has a high selling value $[5,6]$. Additionally, the world market has seen an increasing demand for organic rice [7]. As a result, entrepreneurship determines the farmers' success in adapting to the changing business environment [8]. Thus, entrepreneurial farmers are different from common farmers. Entrepreneurship is a form of activity to build one's attitudes, behaviors and creativity in seeking the desired results [9]. For small farmers who are thriving in the changing environment or global economy, an entrepreneurial culture needs to be fostered in rural communities. Thus, the focus should be shifted from production activities to market-oriented activities [10].

Some studies have shown that attitudes, behaviors and entrepreneurship a businessman must possess include self-efficacy, creativity, commitment, risk-taking nature, confidence, task and result-oriented character, originality, future-oriented character, integrity, perseverance and innovative ideas [3, 11]. The contributing factors in maintaining entrepreneurship and competence include positivity, determination, experiences, perseverance and hard work [12]. These internal factors play a role in the entrepreneurship development.

Entrepreneurship positively affects the agricultural business growth and performance [13]. Performance is a set of achieved results and refers to the actions of achieving and carrying out requested tasks [14]. The performance of farmers who have entrepreneurial attitude can be measured using physical achievements, including (1) the increasing income gained from the amount of production, (2) the expansion of marketing areas, and (3) competitive advantages. However, non-physical success or farmers' social capital is the commitment. The concept of performance is the same as the objective achievements and the production stage [15]. Consequently, entrepreneurship can provide opportunities and assets for entrepreneurs [3].

Entrepreneurship in the agricultural sector will enable farmers to make strategic planning [16], have the courage to implement the plans in farming, as well as supervise and evaluate the farming operations. Furthermore, [17] farmers are basically business owners managers; thus, farming can be considered a business.

The above explanation leads to the need of a study on farmers' entrepreneurship. This study concerns to investigate the influence of the entrepreneurship of rice organic farmers on the farming performance and identify the impacts of farming technique or activities on the farming performance.

\section{Method}

The descriptive approach was employed to population consist of organic rice farmers and carried out between August 2019 and November 2019. The sample of the study was 50 farmers selected using the multistage purposive sampling technique, which refers to the efficient and effective use of various purposive sampling methods altogether.

The purposive sampling technique was used to decide Tasikmalaya regency as the research site because it is one of the organic rice production centers and has exported the rice to many countries. Later, two sub-districts of organic rice centers were chosen: Manonjaya and Salawu sub-districts. Two farmer groups, Sunda Wenang and Harapan Jaya Farmer Groups, were chosen to represent the two sub-districts.

Data were collected in accordance with the study's needs to meet the research objectives through interview, record, and observation. Data were comprised of primary and secondary data. Subsequently, data were analyzed using variance or component-based structural equation modeling (SEM). This approach simultaneously used both measurement 
model and structural model applied to test the validity and reliability, while the structural model to test the causality (hypothesis testing using a predictive modeling). Furthermore, [18] PLS simulated modeling method for analysis because it is not assumed that data must fit the measurement scale, which means the sample size can be small (under 100 samples). The study's empirical model, based on the conceptual framework built on the basis of the theory depicted in Figure 1.

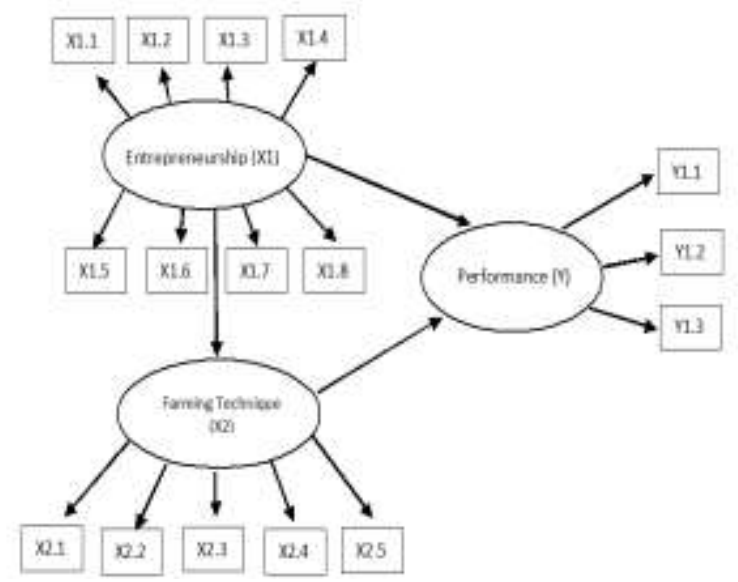

Fig. 1. The Conceptual framework

Notes:

X1.1 : Need for achievement

$\mathrm{X} 1.2$ : Independence

$\mathrm{X} 1.3$ : Acceptance of risk

$\mathrm{X} 1.4$ : Creativity

$\mathrm{X} 1.5$ : Farming knowledge

X1.6 : Farming skills

$\mathrm{X} 1.7$ : Confidence

X1.8 : Market orientation

$\mathrm{X} 2.1$ : Land management

$\mathrm{X} 2.2$ : Cultivation

$\mathrm{X} 2.3$ : Fertilization

X2.4 : Maintenance

X2.5 : Harvesting

Y1.1 : Production

Y1.2 : Profit

Y1.3 : Technique efficiency

\section{Results and Discussion}

\subsection{Effects of Entrepreneurship and Farming Technique on the Farmer Performance}

Analysis of the Effects of Entrepreneurship on the Performance of Rice Organic Farmers described in the path diagram of the model. KWH_PO denoted the entrepreneurship, Tk_BD denoted the farming technique, and Kinerja denoted the farming performance. The path diagram expressed the structural relationship among three variables and constructed the dependent and independet variable. Data processed using a software called WarPLS 2.0 presented in Figure 2. 


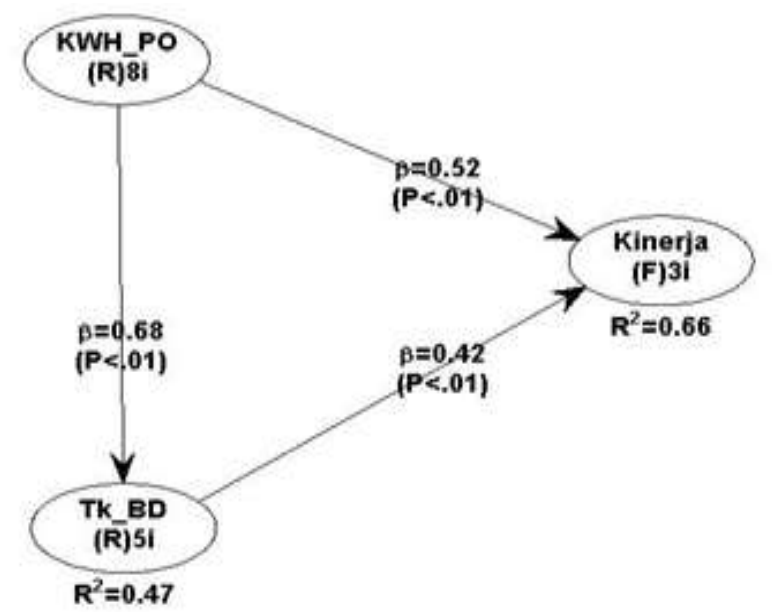

Fig. 2. Path Diagram Model

Table 1. Goodness of Fit Test Results oh Model

\begin{tabular}{|c|c|c|c|c|}
\hline No. & Model Fit and Quality indices & Criterion Fit & $\begin{array}{c}\text { Analysis } \\
\text { Results }\end{array}$ & Conclusion \\
\hline 1. & Average path coeficient (APC) & $\mathrm{P}<0.05$ & $\begin{array}{c}0.541 \\
\mathrm{P}<0.05\end{array}$ & Good \\
\hline 2. & Average R squared (ARS) & $\mathrm{P}<0.05$ & $\begin{array}{c}0.562 \\
\mathrm{P}<0.05\end{array}$ & Good \\
\hline 3. & Average adjusted R-Squared (AARS) & $\mathrm{P}<0.05$ & $\begin{array}{c}0.549 \\
\mathrm{P}<0.05\end{array}$ & Good \\
\hline 4. & Average block VIF & $\begin{array}{l}\text { Acceptable if } \leq 5 \\
\text { Ideally } \leq 3.3\end{array}$ & 1.297 & Ideal \\
\hline 5. & Average full colinerity VIF & $\begin{array}{l}\text { Acceptable if } \leq 5 \\
\text { Ideally } \leq 3.3\end{array}$ & 1.986 & Ideal \\
\hline 6. & Tenenhaus GoF (GoF) & $\begin{array}{l}\text { Small } \geq 0.1 \\
\text { Medium } \geq 0.25 \\
\text { Large } \geq 0.36\end{array}$ & 0.542 & Ideal \\
\hline 7. & Sympson paradox ratio (SPR) & $\begin{array}{l}\text { Acceptable if } \leq 0.7 \\
\text { Ideally } \leq 3.3\end{array}$ & 1.000 & Ideal \\
\hline 8. & $\mathrm{R}$-squared contribution ratio (RSCR) & $\begin{array}{l}\text { Acceptable if } \leq 0.9 \\
\text { Ideally } \leq 3.3\end{array}$ & 1.000 & Ideal \\
\hline 9. & Statistical supresion ratio (SSR) & Acceptable if $\geq 0.7$ & 1.000 & Ideal \\
\hline 10. & $\begin{array}{l}\text { Nonlinier bivariate causality direction } \\
\text { ratio (NLBCDR) }\end{array}$ & Acceptable if $\geq 0.7$ & 1.000 & Ideal \\
\hline 11. & Average adjusted R-Squared (AARS) & $\mathrm{P}<0.05$ & $\begin{array}{c}0.549 \\
\mathrm{P}<0.05 \\
\end{array}$ & Good \\
\hline 12. & Average block VIF (AVIF) & $\begin{array}{l}\text { Acceptable if } \leq 5 \\
\text { Ideally } \leq 3.3\end{array}$ & 1.297 & Ideal \\
\hline 13. & Average full colinerity VIF & $\begin{array}{l}\text { Acceptable if } \leq 5 \\
\text { Ideally } \leq 3.3\end{array}$ & 1.986 & Ideal \\
\hline 14. & Tenenhaus GoF (GoF) & $\begin{array}{l}\text { Small } \geq 0.1 \\
\text { Medium } \geq 0.25 \\
\text { Large } \geq 0.36\end{array}$ & 0.542 & Ideal \\
\hline 15. & Sympson paradox ratio (SPR) & $\begin{array}{l}\text { Acceptable if } \leq 0.9 \\
\text { Ideally } \leq 3.3\end{array}$ & 1.000 & Ideal \\
\hline 16. & R-squared contribution ratio (RSCR) & $\begin{array}{l}\text { Acceptable if } \leq 0.7 \\
\text { Ideally } \leq 3.3\end{array}$ & 1.000 & Ideal \\
\hline 17. & Statistical suppresion ratio (SSR) & Acceptable if $\geq 0.7$ & 1.000 & Ideal \\
\hline 18. & $\begin{array}{l}\text { Nonliner bivariate causality direction } \\
\text { ratio (NLBCDR) }\end{array}$ & Acceptable if $\geq 0.7$ & 1.000 & Ideal \\
\hline
\end{tabular}


The model applied to the estimation requires at least two indicators, model fit and quality [19]. The fulfilled criteria of model fit and quality indices describing the goodness of fit are APC, ARS, paradox ratio, $R$-squared contribution ratio and Statistical suppression ratio.

In this study, the latent variables, entrepreneurship (X1), farming techniques or activities (X2), were the measurement models implementing reflective indicators; thus, the evaluation of the measurement model representing outer model was attained by examining the convergent and discriminant validity of the indicators as well as the composite reliability. Outer model test results are provided in Table 2.

Table 2. Outer Model Test Results

\begin{tabular}{|c|l|c|c|}
\hline Variable & \multicolumn{1}{|c|}{ Indicator/Item } & Outer Loading & p-value \\
\hline \multirow{4}{*}{$\begin{array}{c}\text { Entrepreneurship } \\
\text { (X1) }\end{array}$} & Need for achievement & 0.808 & $<0.001$ \\
\cline { 2 - 4 } & Independence & 0.167 & 0.108 \\
\cline { 2 - 4 } & Acceptance of risk & 0.393 & 0.001 \\
\cline { 2 - 4 } & Creativity & 0.029 & 0.417 \\
\cline { 2 - 4 } & Farming knowledge & 0.807 & $<0.001$ \\
\cline { 2 - 4 } & Farming skills & 0.752 & $<0.001$ \\
\cline { 2 - 4 } & Confidence & 0.827 & $<0.001$ \\
\cline { 2 - 4 } & Market orientation & 0.598 & $<0.001$ \\
\hline \multirow{4}{*}{$\begin{array}{c}\text { Farming } \\
\text { Achnique/Farming } \\
\text { Activities }\end{array}$} & Land management & 0.419 & $<0.001$ \\
\cline { 2 - 4 }$(\mathrm{X} 2)$ & Cultivation & 0.298 & $<0.011$ \\
\cline { 2 - 4 } & Fertilization & 0.688 & $<0.001$ \\
\cline { 2 - 4 } & Maintenance & 0.841 & $<0.001$ \\
\cline { 2 - 4 } & Harvesting & 0.800 & $<0.0001$ \\
\hline \multirow{2}{*}{$\begin{array}{c}\text { Performance } \\
(Y)\end{array}$} & Production & 0.997 & 0.457 \\
\cline { 2 - 4 } & Profit & 0.015 & \\
\cline { 2 - 4 } & Technique efficiency & & \\
\hline
\end{tabular}

Table 2 illustrates that indicators giving positive impacts on the measurement of farmers' entrepreneurship are the need for achievement (X1.1), farming knowledge (X1.5), farming skills (X1.6), confidence (X1.7), market orientation (X1.8) in which each has outer loading value $0.808,0.807,0.752,0.827$ and 0.598 respectively at the error rate of $5 \%$. These results indicate that the indicators are valid to measure the variable of farmers' entrepreneurship. Results of analysis also show that confidence is the strongest indicator in reflecting the farmers' entrepreneurship since it has the highest outer loading value 0.827 .

Results of outer model testing on the variable of farming techniques or activities (X2) show that four indicators, land management (X2.1), fertilization (X2.3), maintenance (X2.4) and harvesting (X2.5), positively affect the measurement of the farmers' farming techniques. The status of farming techniques depicting land management, cultivation, fertilization, maintenance and harvesting, was reflected by the higher value of the indicators. The four indicators had outer loading values $0.414,0.688,0.841$ and 0.800 respectively at the $5 \%$ of error rate. Among these four influential indicators, the maintenance indicator is the most dominant in reflecting the status of farming activities or techniques.

The test shows a positive influence of the indicators of production (Y1.1) and profit (Y1.2) on the measurement of farming performance. These two indicators had the same outer loading value 0.997 at the $5 \%$ error rate. Production and profit should be the indicators measuring performance because farmers can increase yields and income. The two indicators are equally dominant and can primarily reflect the farming performance. However, the technique efficiency indicator does not influence the farming performance measurement. 
Innovation uttered by entrepreneurial character was described in to business change processes and business enterprise characteristics, futhermore, supporting diversification and determining the economic benefit [20, 21, 22]. Entrepreneurial studied by [23] got the results that the opportunity-seeking, innovation, risk-taking attitudes as entrepreneurial indicators enhancing the rural development. Performance perspective by [24] separated in to specific competence managing resources, financial capacity including initiation and development, and entrepreneurial efforts in making innovation resulting impacts to the performance. Intepretation about risk-taking attitudes describing good managing risk showed more profitable and business growth [25]. The profitable farming as performance outlined in [26] was resulted from innovation, knowledge improvement, and proactive behavior.

Analysis results of latent variables were employed to answer the hypotheses of variables affecting farming performance. Analysis results of latent variables and the structural path coefficients are written in Table 3 below.

Table 3. Results Latent Variable Coefficients Results

\begin{tabular}{|l|c|c|c|}
\hline & $\begin{array}{c}\text { Kwh_PO } \\
\text { X1 }\end{array}$ & $\begin{array}{c}\text { Farming } \\
\text { Technique } \\
\text { X2 }\end{array}$ & $\begin{array}{c}\text { Performance } \\
\text { Y }\end{array}$ \\
\hline R-squared & & & 0.657 \\
Adj R-squared & & & 0.642 \\
\hline Composite reliab & 0.797 & 0.626 & 0.800 \\
\hline Cornbach alpha & 0.713 & 0.399 & 0.601 \\
\hline Avg. Var. Extrac. & 1.914 & 0.417 & 0.663 \\
\hline Full collin. VIF & 1.914 & 2.066 & 1.979 \\
\hline Q-squared & & 0.476 & 0.651 \\
\hline
\end{tabular}

Based on the above table, the R-squared value is 0.657 . R-squared value shows the proportion of response variables that can be explained by predictor variables, entrepreneurship and farming technique variables. The organic rice farmers' performance was influenced by entrepreneurship and farming technique variables by $65.7 \%$ and $34.3 \%$ was the influence of variables not included in the research and containing errors.

Farming technique depicted on the utilization of the tools to cultivate the land was analyzed by [27]. This findings also regarded with the technology adoption by farmers using machine. [28] Entrepreneurial capacity that described the business structure, competencies and the understanding of achievement. The performance was indicated with the growth of the business or the farming performance that highlited the entrepreneurial performance of the person doing the business or farming activities. The entrepreneur characteristics was argumented then [29] explaining the education, experience, and skills contributing to the performance of business, by definition, entrepreneurial experience was greatly meaningful factor because of lifestyle business regarding with survival and maintaining the income, by consistent with [30]. [31] The innovation of farming related with farming technique and profitability encouraged the region, then the coopetitive farm entrepreneur had reason to develop the collaboration among farmers. Entrepreneurial approach was described by [32] confirming that entrepreneurial created novelties in organic farming from production through the marketing system. [33] Study in the strong contribution of entrepreneurship described using risk taking, innovation, creativity, achievement, self condidence, and relationship with others.

The composite reliability value and the cronbach's alpha value depicted in Table 3. can be used to determine the reliability of the research instrument. The composite reliability value was greater than 7 . The values of entrepreneurship and farmers' performance variables more than 7 explained the research instrument both good and fair reliability 
levels. On the other hand, the farming technique had the value $>6$, signifying that this variable has fair reliability level. Thus, these variables have fulfilled the reliability requirements.

Full collinearity VIF is the results of full collinearity assessment, including vertical and lateral multicollinearity. Analysis results suggest that the full collinearity VIF was $<3.3$, meaning that the model has no both vertical and lateral collinearity problems as well as common method bias. The table clearly shows that the Q-squared value was bigger than zero. Q-squared is used to examine the acceptable predictive validity of predictor latent variables at the criterion variable regarding the connection with endogenous latent variables.

\subsection{Warp PLS Analysis Results}

The assessment of the structural path coefficient was conducted in order to discover the extent of the influence of each variable. The results were obtained from the inner model of WarpPLS analysis results; thus, the direct effects of variables are visible. The analysis results inner model of WarpPLS presented in Table 4. Committed with p-value less than 0.01 .

Table 4. Inner Model of WarpPLS Analysis Results

\begin{tabular}{|l|c|c|c|}
\hline \multicolumn{1}{|c|}{ Relationship } & Coefficient & p-value & Conclusion \\
\hline $\begin{array}{l}\text { Entrepreneurship } \rightarrow \\
\text { Farming Activites }\end{array}$ & 0.68 & $<0.01$ & Significant \\
\hline $\begin{array}{l}\text { Entrepreneurship } \rightarrow \\
\text { Farming Performance }\end{array}$ & 0.52 & $<0.01$ & Significant \\
\hline $\begin{array}{l}\text { Farming Activites } \rightarrow \\
\text { Farming Performance }\end{array}$ & 0.42 & $<0.01$ & Significant \\
\hline
\end{tabular}

Other research was done by [34] the performance that was represented by financial performance, indicating the ability of farmer to decrease the cost of farming and doing the efficient activities. [35] argumented on the research about entrepreneurial orientation toward the farm business performance that resulted knowledge having important role determine the farming performance, this in line with [36] describing the ability of knowledge acquisition. [37] Explaination of the farming performance amployed the skill of farmer to sell more products, cost management and managing the strategic goals. [38] separated the individual characteristics to the indicators such as experience, farm business motivation and perspective toward business. Whereas, the entrepreneurial behavior interpreted in to innovative, risk taking, independent, opportunity seeing, and earnest pursuit. The farming technique variable employed by [39] showed the impact to the farming performance.

From Table 4. the values of the direct effect of the farmers' entrepreneurship on the organic rice farming performance were 0.52 and $p<0.01$. The regression coefficient value of 0.52 indicates that the increased entrepreneurship of the organic rice farmers influences the improvement of the farming performance by 0.52 with the assumption that other variables were constant. Statistical test results show that the farmers' growing entrepreneurship significantly affects the farmers' performance.

The influence of entrepreneurship (X1) on farming technique (X2) was indicated by the structural coefficient value 0.68 and engaged the $p$-value $<0.01$. The $p$-value $<0.05$ and the cofficient having possitive value constructed that entrepreneurship (X1) significantly influence on farming technique (X2). It can be concluded that the higher the farmers' entrepreneurship (X1), the more powerful the farmers' farming technique/activities (X2). 
The effect of entrepreneurship (X1) on the organic rice farming performance (Y) is shown by the structural coefficient 0.52 and concerned $0.01 \mathrm{p}$-value. Since the p-value $<0.0 .5$, it is assumed there is a significant impact of entrepreneurship (X1) on farming performance (Y). Thus, the higher the farmers' entrepreneurship (X1), the stronger the organic rice farmers' performance $(\mathrm{Y})$.

The influence of rice farming activities or technique (X2) on organic rice farming performance $(\mathrm{Y})$ is indicated by the structural coefficient 0.42 and the p-value $<0.001$. Since occupy the p-value $<0.05$ and the positive coefficient, it is clear that farming activities/technique (X2) have significant and positive influence on the farming performance (Y). Therefore, the better the farming activities/technique (X2), the stronger the farmers' performance $(\mathrm{Y})$.

\section{Conclusion}

Entrepreneurship significantly and positively affects farming techniques. Entrepreneurship has significant and positive influence on the organic rice farming performance. In addition, farming technique is significantly and positively influential on the organic rice farming performance.

Acknowledments. This activity was supported by Research and Community Services Directorate of General Directorate of Research Reinforcement and Development, Ministry of Research, Technology, and Higher Education. The authors thank to Research and Community Services, University of Siliwangi for helping and supporting the reserch.

\section{Reference}

1. S. M. Chege, D. Wang, Journal of Rural Studies, 77 (2020).

2. W. Morris, A. Henley, D. Dowell, Journal of Rural Studies, 53 (2017).

3. Choudhury. Easwaran. Journal of Global Entrepreneurship Research. 9, 59 (2019).

4. S. Fahad, J. Wang, Land Use Policy, 79 (2018).

5. A. Singh, P. Verma, Journal of Cleaner Production, 167 (2017).

6. C. F. Oroian, C. O. Safirescu, R. Harun, G. O. Chiciudean, F.H. Arion, I. C. Muresan, B. M. Bordeanu, Sustainability 9, 1559 (2017).

7. C. Nuraini. Theses UGM. (2018).

8. O. Mirzaei, E. T. Micheels, A. Boecker, International Food and Agribusiness Management Review 19, 2 (2016).

9. E.S. Prabawati, A. P.i Ayuningtya, R. P. Ramadhani, P. K. Pratama, M. Indarto, E. Erawati, Jurnal Teknologi Bahan Alami, 2 (2018).

10. B. M. Mukindia. . International Journal of Social Sciences and Project Planning Management, 1 (2014).

11. C. Dorin, G. Alexandru, Literature Review The annual of the University of Canada, 23 (2014).

12. M. S. Satar, S. Natasha Asia Pacific Journal of Innovation and Entrepreneurship 13, 1 (2019).

13. A. A. Mamun, M. Mohiuddin, S. A. Fazal, G. B. Ahmad, Management Research Review 41, 1 (2018).

14. H. Wang, D. Oneata, J. Verbeek, C. Schmid, International Journal of Computer Vision, 119 (2016).

15. S. S. Durmuşoğlu, G. Apfelthaler, D. Z. Nayir, R. Alvarez, T. Mughan. Industrial Marketing Management 41, 4 (2012). 
16. F. Lourenço, N. Sappleton, A. Dardaine-Edwards, G. McElwee, R. Cheng, D. W. Taylor, A. G. Taylor, Gender in Management 29, 7 (2014).

17. L. Kallio, E. Heiskanen, E. Apajalahti, K. Matschoss, Energy Research \& Social Science, 65 (2020).

18. N. Kock, P. Hadaya, Information System Journal, (2016).

19. Solimun, A. A. R. Fernandes, Nurjannah, Metode Statistika Multivariat, Pemodelan Persamaan Struktural (SEM), (UB Press, Malang, 2017).

20. F. Ali, S. M. Rasoolimanesh, M. Sarstedt, C. Ringle, K. Ryu, International Journal of Contemporary Hospitality Management 30, 1 (2018).

21. C. Barbieri. Journal of Rural and Community Development 5, 1/2 (2010)

22. C. Barbieri, Journal of Sustainable Tourism 21, 2 (2013).

23. H. S. R. Rosairo, D. J. Potts. Journal of Agribusiness in Developing and Emerging Economies 6, 1 (2016)

24. J. Grande, E. L. Madsenb, O. J. Borchb, Entrepreneurship \& Regional Development: An International Journal 23, 3-4 (2011)

25. N. M. Shadbolt, F.Olubode-Awosolab, International Food and Agribusiness Management Review 19, 2 (2016)

26. R. Díaz-Pichardo, C. Cantú-González, P. López-Hernández, G. McElwee, The Journal of Entrepreneurship, 21, 1 (2012)

27. M. F. Umar, I. Nugroho, Darmadji, Suwarta. Journal of Socioeconomics and Development 3, 1 (2020)

28. K. V. Sebikari, Int Journal of Social Sciences Management and Entrepreneurship 3, 1 (2019)

29. J. A. Felı'cio, E. Couto, J. Caiado. Management Decision 52, 2 (2014).

30. D. Radicic, R. Bennett, G. Newton, Journal of Rural Studies, 55 (2017)

31. V. Ratten, International Journal of Sociology and Social Policy 38, 1/2 (2018)

32. K. Shrestha, G. Shrestha, P. R. Pandey, The Journal of Agriculture and Environment, 15 (2014).

33. P.Mappigau, Jusni, International Journal of Business and Social Science 3, 6 (2012)

34. S. Nieuwoudt, Disertation, (University of the Free State, Bloemfontein, 2016)

35. X. Gellynck, J. C'ardenas, Z. Pieniak, W. Verbeke, Agribusiness An International Journal (2014)

36. T. B. Udimal, Z. Jincai, I. A.Gumah. Asia Pacific Journal of Innovation and Entrepreneurship 13, 2 (2019)

37. T. Q. Dung, L. B. Bonney, R P. Adhikari, M. P. Miles, Supply Chain Management: An International Journal 25, 5 (2020).

38. H. Ashilina, L. M. Baga1, S. Jahroh, J. ISSAAS 25, 2 (2019)

39. B. Mupfasoni, A. Kessler, T. Lans, Journal of Small Business and Enterprise Development 25, 1 (2018) 